\title{
BRIDGING TOURIST ATTRACTIONS. THE ROLE OF WATERBUSES IN URBAN TOURISM DEVELOPMENT: THE CASE OF THE COASTAL CITY OF GDAŃSK (POLAND)
}

\author{
Maciej TARKOWSKI* \\ University of Gdańsk, Faculty of Oceanography and Geography, Institute of Geography, Division of Regional \\ Development, Bażyńskiego 4, 80-309, Gdańsk, Poland, e-mail: maciej.tarkowski@ug.edu.pl \\ Marcin POŁOM \\ University of Gdańsk, Faculty of Oceanography and Geography, Institute of Geography, Division of Regional \\ Development, Bażyńskiego 4, 80-309, Gdańsk, Poland, e-mail: marcin.polom@ug.edu.pl \\ Krystian PUZDRAKIEWICZ \\ University of Gdańsk, Faculty of Oceanography and Geography, Institute of Geography, Division of Regional \\ Development, Bażyńskiego 4, 80-309, Gdańsk, Poland, e-mail: krystian.puzdrakiewicz@ug.edu.pl
}

\begin{abstract}
Citation: Tarkowski, M., Połom, M., \& Puzdrakiewicz, K. (2021). BRIDGING TOURIST ATTRACTIONS. THE ROLE OF WATERBUSES IN URBAN TOURISM DEVELOPMENT: THE CASE OF THE COASTAL CITY OF GDAŃSK (POLAND). GeoJournal of Tourism and Geosites, 34(1), 126-131. https://doi.org/10.30892/gtg.34116-627
\end{abstract}

\begin{abstract}
Identification of the role of the waterbus system in the development of tourism in a large coastal city - a tourist center of international importance. Cartographic materials, qualitative and quantitative data on the waterbus system, spatial development and tourist traffic were used. Quantitative temporal and spatial analyses were conducted, including GIS analyses. Service of the tourist traffic is the dominant function of the waterbus in Gdańsk. This is determined by three categories of factors: (i) the seasonal nature of the system and a low level of integration with the public transport system; (ii) low potential demand for transport services due to the fact that most of the stops are far away from large residential or work centers; (iii) proximity of most of the city's main tourist attractions to the stops. The obtained results are helpful in programming the development of public transport systems, especially in large tourist coastal cities. The conditions of spatial development are of key importance for shaping the dominant function of the waterbus.
\end{abstract}

Key words: tourist attractions, waterbus, urban tourism, public transport system, Gdańsk

\section{INTRODUCTION}

The aim of the article is to identify the role of the waterbus system in the development of tourism in a large coastal city, such as Gdańsk, which is also a tourist center of international importance. The basic premise for undertaking the research is the fact that the system has been operating for a relatively short time (since 2012) and has not been sufficiently covered in the subject literature yet. Few works directly related to the discussed system appeared shortly after its launch, and they have a limited empirical value (Cieśliński and Chromniak, 2013; Kizielewicz, 2014). On the other hand, in later works, the issue of servicing tourist traffic was not the main point of focus (MiszewskaUrbańska and Apollo, 2016; Połom et al., 2020). Moreover, organizational and functional dissonance is also conducive to taking up the issue. Formally, Zarząd Transportu Miejskiego (the Municipal Transport Authority) is the operator of this transport. Therefore, waterbuses are part of the public transport system. At the same time, they operate during the tourist season, which indicates that their main function is to handle tourist traffic. The problem of the dominant function of public transport in tourist cities is recognized in the literature (Le-Klähn and Hall, 2015). The following analysis attempts to indicate the conditions and factors determining the primary function of the water tram system in the city Gdańsk. The spatial scope of the analysis covers the territory of this city. In particular, the areas in the vicinity (1000 m radius) of waterbus stops were taken into account. The main period of the analysis covers the years 2012-2018.

Waterbuses are a type of city public transport. This fact places the present analysis in the new mobilities paradigm that has been developing for less than two decades. It integrates the issues of urban transport, anthropogenic climate change and energy tran sformation (Sheller and Urry, 2016). It is part of the research stream devoted to sustainability, and in particular to sustainable accessibility (Gil Sola et al., 2018). In this perspective, waterbuses are one of the means of transport aimed at reducing the dominance of private cars in the modal split.

Waterbuses are not a common form of urban transport. The structure of the hydrographic network is of fundamental importance for their development - both in terms of the navigability of individual reservoirs and their location in relation to areas concentrating daily migrations. Cheemakurthy et al. (2017) identified 23 cities in the world where this measure plays a significant role in the transport system. In thirteen cases, these systems were large scale (>7 lines, high number of stops); six were in the medium scale group (4-6 lines, medium number of stops), and four in the small scale category (1-3 lines, limited number of stops). These authors also distinguished three basic types of ferry systems: type A (linear) - routes where boat services traverse along a river or water body stopping at multiple destinations connecting points of interest along a waterfront; type B - shorter routes with two or three stops either in a simple river crossing or triangular three-point stop configuration; type $\mathrm{C}$ - routes linking suburbs with the inner-city area by long, low-frequent connections. The role of city ferries in increasing the cohesion of the transport system and transport accessibility in coastal cities is relatively often undertaken in scientific research (Ercoli et al., 2015; Sandell, 2017; Chen et al., 2017; Bignon and Pojani, 2018; Große et al., 2018). Another thread concerns the directions of development of this type of transport.

On the one hand, the role of technical innovations in the development of urban passenger shipping is emphasized. In particular, the importance implementing an electric/hybrid drive is emphasized, which allows for a deep reduction of operating costs and an increase in the comfort of travel and operation (Gagatsi et al., 2016; Guarnieri et al., 2018). This approach is dominant in cities in hi ghly developed countries, capable of mobilizing sufficiently high investment outlays. On the other hand, the leading role of transformations of urban

\footnotetext{
* Corresponding author
} 
regimes in the field of urban transport is emphasized, resulting mainly in optimization and organizational and structural transformations only supported by technical innovations (Bandyopadhayay and Banerjee, 2017; Ghosh and Schot, 2018).

Many port cities also have intense tourist traffic. Public transport is oriented towards its service to varying degrees (Le-Klähn and Hall, 2015). Urban passenger shipping seems to play a special role in this field. In some cities, it even specializes in servicing tourist traffic. The degree of specialization depends on the overall tourist attractiveness of the city, the nature of the places connected by the shipping lines (to what extent these are places of residence and work and to what extent of spending leisure time), and the competitiveness of other types of urban transport (Tanko and Burke, 2017). Based on the literature review, Tan and Ismail (2020) indicate that the existing transport modes in the destination will affect tourist movement, especially in terms of the designated route of transport and walkability to tourist attractions. As further analysis shows, these factors will be of key importance for the operation of waterbuses in Gdańsk.

\section{Case study - Gdańsk}

The city of Gdańsk is located in northern Poland on the Gulf of Gdańsk, which is part of the Baltic Sea (Figure 1). It is one of the most important tourism centers in Poland; it is also ranked as an important European center. It has a competitive accommodation base in terms of the volume of resources, quality and prices (Obrochta, 2019). Annually, the city is visited by 2-2.5 million visitors. In 2017, the number of visitors and tourists was estimated at 2.7 million. Of these, two-thirds (1.7 million) were tourists, i.e. people using accommodation (Bęben et al., 2018). During the three summer months - June, July and August - the city was visited by about 837,000 guests, i.e. about $30 \%$ of the whole-year number of tourists and visitors (Pomeranian Scientific Institute, 2017). The above-mentioned study shows an image of the average tourist as a rather young person (less than 44 years old), most often with higher education, with a rather good financial situation, coming for at least a few days with accompanying persons, mainly for leisure, which takes the form of sightseeing and walking.

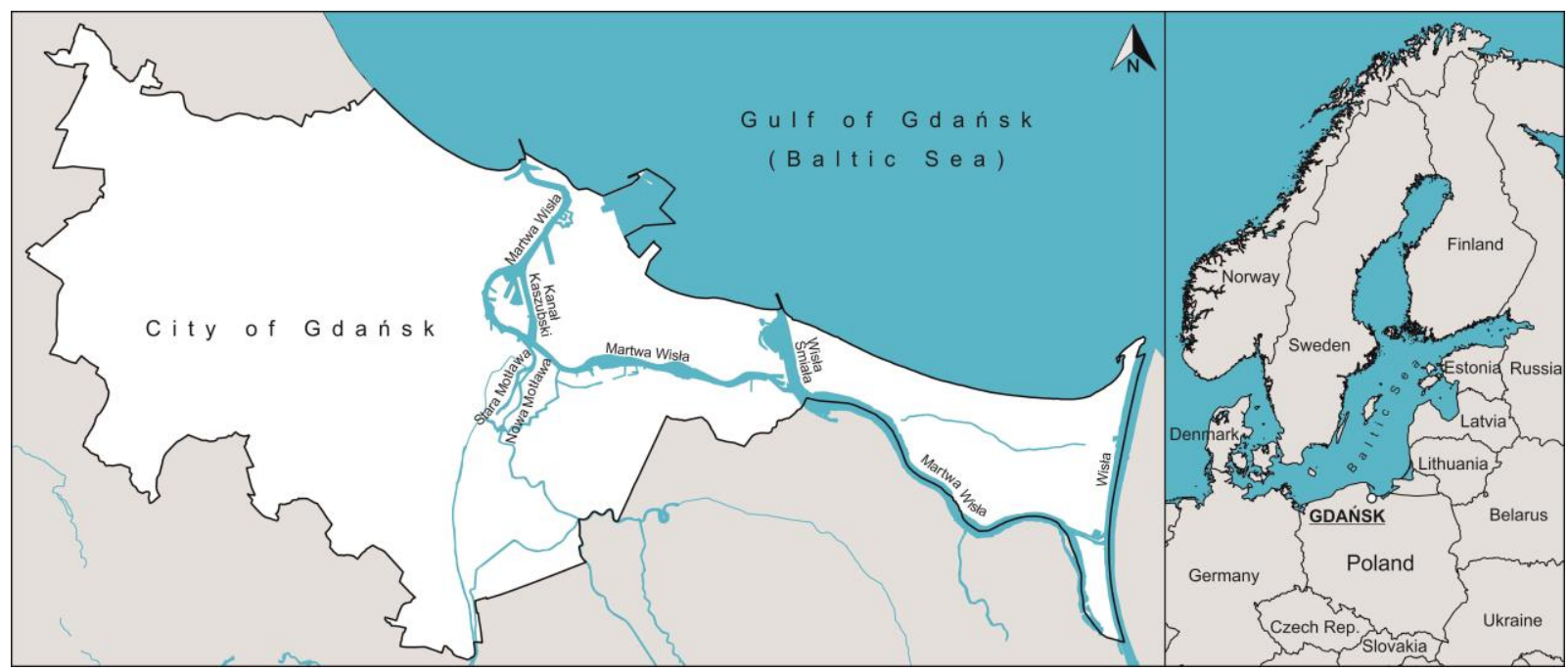

Figure 1. Location of the city of Gdansk (Source: own elaboration)

Within its current administrative borders, there are waterways and fairways using the hydrographic system based on the Martwa Wisła with the Kanał Kaszubski, the Wisła Smiała, the Nowa Motława and the Stara Motława rivers. Gdańsk is a city with a thousandyear history, in which its coastal and riparian location has always been of paramount importance. The spatial development of the city initially concentrated along rivers and canals, and then covered the coastal zone of the Gulf of Gdańsk. Rivers and canals in Gdańsk are currently used mainly by passenger vessels of a tourist and recreational nature. The greatest concentration of the tourist traffic is in the Śródmieście area, with quays for local and regional passenger shipping and yacht harbors. In 2006, the first waterbuses were launched in the Gdańsk urban region. The initiative of the municipal authorities was aimed at increasing the attractiveness (frequency of routes and ticket prices) of coastal tourist shipping. However, it was not until 2012 that reorganization was carried out, involving the launch of two waterbus lines operating in the inner waters of Gdańsk. As part of the project co-financed from the EU funds, 10 waterbus stops were built. In this way, the system's elementary infrastructure, which is the subject of this analysis, was created.

\section{MATERIALS AND METHODS}

The research procedure was divided into three basic stages (Table 1) aimed at achieving specific research goals. At each stage, a set of appropriate research methods was applied, adequate to the problem and available sources. In the first stage, the focus was on the supply side of the waterbus system. The research was based, to the necessary extent, on quantitative data, which enable defining the system size and its operational capacity. The assessment of this parameters was the first to identify the role of waterbuses in urban transport system.

Table 1. Research stages, relevant detailed aims, materials and methods (Source: own elaboration)

\begin{tabular}{|c|l|l|}
\hline Stage & \multicolumn{1}{|c|}{ Research objective } & \multicolumn{1}{|c|}{ Materials and methods } \\
\hline 1 & $\begin{array}{l}\text { Characteristics of waterbus operation supply (system size and type, } \\
\text { type and number of vessels, passenger capacity, frequency of routes) }\end{array}$ & $\begin{array}{l}\text { Materials: data of the transport operator (Municipal Transport Authority, } \\
\text { 2018a) and the results of the expert opinion on the operation of waterbuses } \\
\text { (Gdańsk Economic Development Agency, 2018). } \\
\text { Methods: qualitative and quantitative temporal and spatial analyses. }\end{array}$ \\
\hline 2 & $\begin{array}{l}\text { Identification of spatial determinants of a demand for waterbus } \\
\text { transport (hydrographic conditions; distribution of inhabitants, } \\
\text { workplaces and tourist attractions as well as investment areas) }\end{array}$ & $\begin{array}{l}\text { Materials: geodetic and cartographic data from public resources (Geoportal, } \\
\text { 2018; Gdansk Development Office, 2018); data with high spatial resolution on } \\
\text { the number of inhabitants, workplaces (Gdansk Development Office, 2016), } \\
\text { location of tourist attractions (Bęben et al., 2018). Methods: GIS analysis. }\end{array}$ \\
\hline 3 & $\begin{array}{l}\text { Defining the importance of tourists function of waterbus system } \\
\text { (passenger traffic intensity by stops and importance of tourist } \\
\text { attractions located close to waterbus stops) }\end{array}$ & $\begin{array}{l}\text { Materials: data of the transport operator (Municipal Transport Authority, } \\
\text { 2018b), reports on tourist traffic (Bęben et al., 2018). } \\
\text { Methods: quantitative analysis of passenger traffic and survey results data. }\end{array}$ \\
\hline
\end{tabular}


In the second stage, the spatial determinants of a demand for waterbus services were identified. These studies were carried out based on spatial data and the related quantitative data using GIS methods and tools. In the third stage, the intensity of passenger traffic compared to the nature and the importance of tourist attractions within a radius of $1000 \mathrm{~m}$ from waterbus stops were analyzed. Research indicates (Gurgul, 2018) that this is an acceptable walking distance radius of accessibility to attractions in waterside zones. The compilation of partial results obtained at the described stages of the research enabled achieving the main objective of the article -defining the role of waterbuses in servicing tourist traffic in the analyzed city.

\section{RESULTS AND DISCUSSION}

The results were discussed in relation to the specific research objectives (Table 1). First, the supply side of the waterbus system in Gdańsk are presented, and then the focus is shifted to the spatial determinants of the functioning of this system. Finally, the results of the analysis of the passenger traffic and the distribution and importance of tourist attractions close to waterbus stops are presented.

The waterbus system in Gdańsk consisted of two lines, thirteen stops and three vessels. In comparison to other similar systems, it should be classified as small scale (Cheemakurthy et al., 2018). The nature of the used fleet and the degree of filling indicate the heterogeneity of the waterbus system in Gdańsk. In consistence with the proposal by Cheemakurthy et al. (2018), line F5 repre sents type A (linear) routes, where boat services traverse along a river or water body stopping at multiple destinations connecting points of interest along a waterfront. By contrast, line F6 corresponds to type C, linking suburbs with the inner-city area by long, low-frequent connections. In the years 2012-2017, the waterbus lines operated with a frequency of 3 connections a day, and since 2018 the number of connections on the F5 line was doubled. So far, operator tenders have been announced twice for the years 2015-2017 and 2018-2020. In both cases, the company Żegluga Gdańska was selected. Sonica and Sonica I ships, which are characterized by a low superstructure allowing them to sail under permanent bridges, were specially purchased to operate the line. The vessels can take 40 passengers and 5 bicycles. A larger ship with a capacity of 140 passengers and bicycles operates on the F6 line since 2018.

The length of the F5 route is approx. $12.8 \mathrm{~km}$, and one-way cruise time takes approx. $98 \mathrm{~min}$. The length of the F6 route is $14.3 \mathrm{~km}$, and it takes comparable cruise time of approx. $100 \mathrm{~min}$. The volume of the transport service offered by the waterbus system compared to other public transport modes showed very low. Leading urban transport operator uses 252 buses and 135 tram sets. Almost e very tram can carry more passenger than most giant waterbus vessel (Gdańsk Buses and Trams, 2020). Public transport network consists of 10 tram and 65 bus lines serving 730 stops - also located in neighbouring municipalities (Municipal Transport Authority, 2020).

The tourist function of waterbuses is forced by unfavorable, from the point of view of the functioning of the municipal public transport system, spatial conditions. Near the stops of both routes, there are no significant urban population centers and workplaces, which is a key barrier to development (Thompson et al., 2007). The only major concentration is the city center. However, this is an area with good transportation links to other parts of the city, including those located close to the waterbus stops (Figure 2). Therefore, both types of transport are competitive. Considering the small scale, the fact that waterbuses only operate during the tourist season, that they run very infrequently and that travel costs are relatively high, it should be considered that actually they are not part of the urban public transport system.

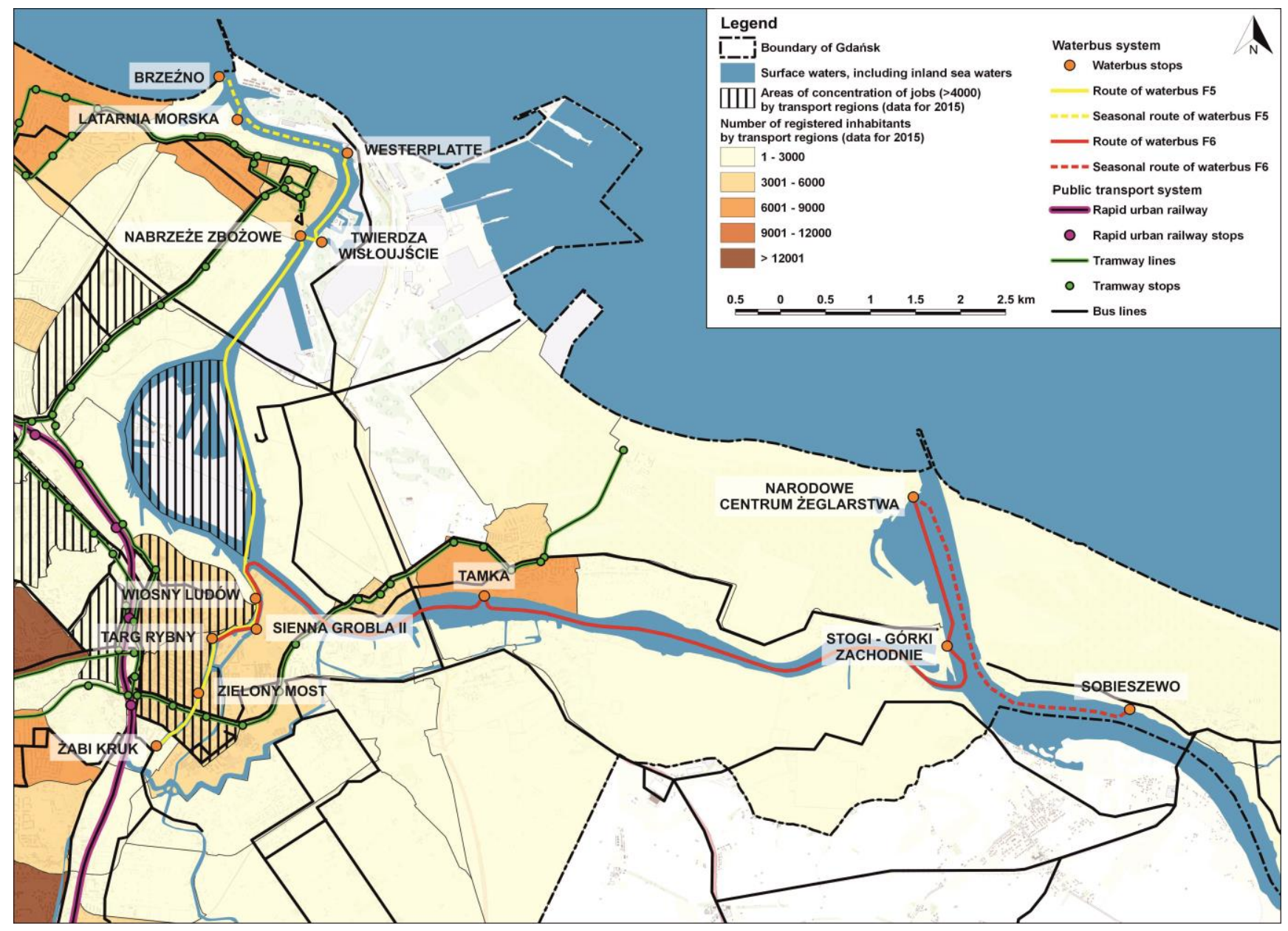

Figure 2. Spatial patterns of population and workplaces along waterbus routes in Gdańsk

(Source: own elaboration based on Gdańsk Development Office, 2016; Gdańsk Development Office, 2018) 
The tourist function results not only from the low accessibility of stops to places of residence and work. Primarily, it results from the high attractiveness of the vicinity of stops for recreation and tourism (Figure 3). The waterbus also offers competitive connections in terms of travel time compared to other means of public transport. The latter often have to take a roundabout route to use sparsely situated bridges. Waterbuses have a particularly large advantage in serving attractions located on the opposite banks of the mouth of the Vistula.

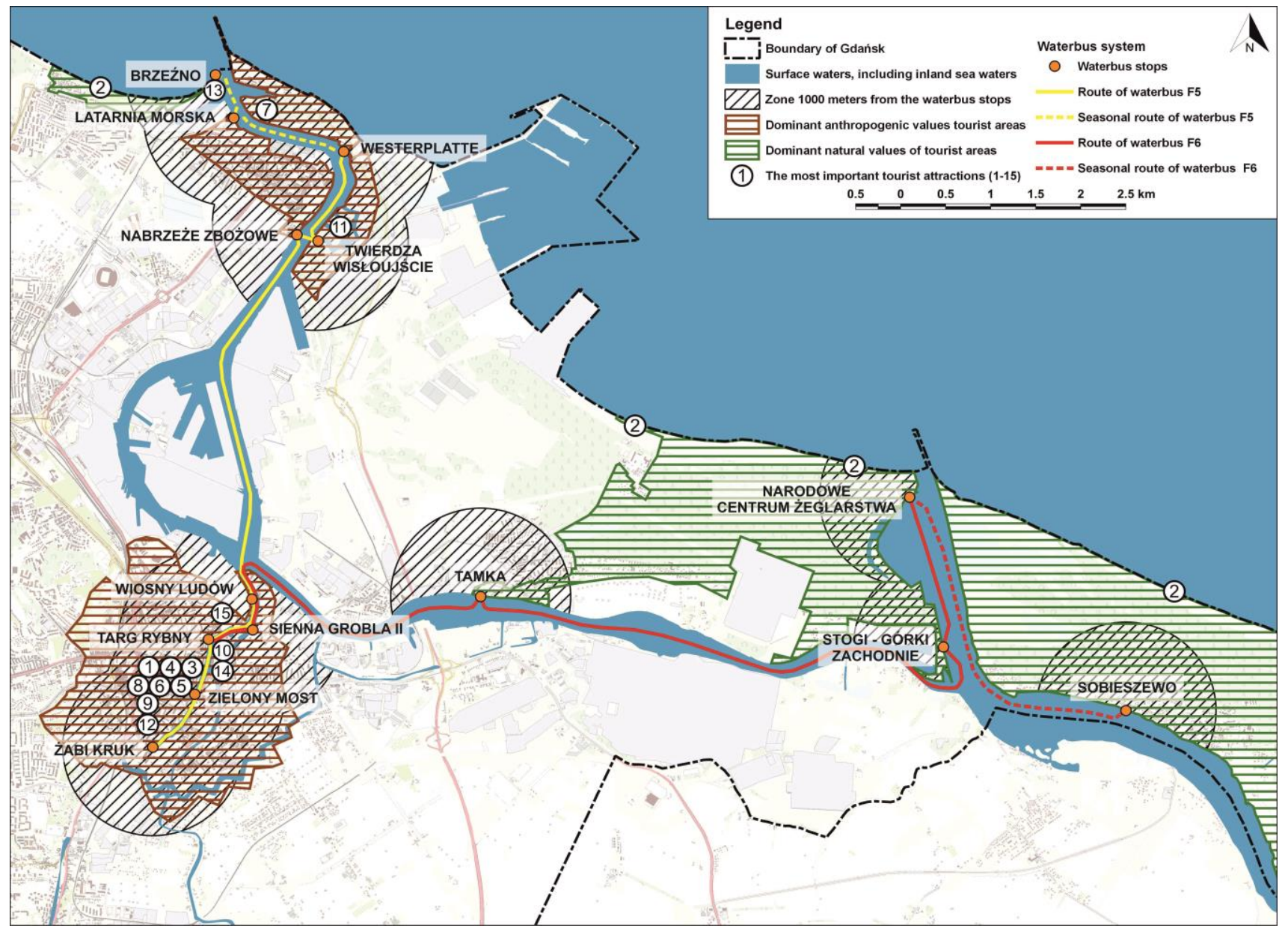

Figure 3. Spatial patterns of tourist's attractions along waterbus lines in Gdańsk. (Source: own elaboration based on Geoportal, 2018; Bęben et al., 2018)

Table 2. The number of passengers on the waterbus lines in 2012-2018 (Source: own elaboration based on materials of Gdańsk Economic Development Agency, 2018; Municipal Transport Authority, 2018b)

\begin{tabular}{|c|c|c|}
\hline Year & Number of passengers & YoY increase (\%) \\
\hline 2012 & 11,375 & - \\
\hline 2013 & 25,794 & 127 \\
\hline 2014 & 31,801 & 23 \\
\hline 2015 & 43,885 & 38 \\
\hline 2016 & 47,240 & 8 \\
\hline 2017 & 48,367 & 2 \\
\hline 2018 & 65,627 & 36 \\
\hline
\end{tabular}

Table 3. The average number of waterbuses passengers per day by lines and directions

in Gdańsk in 2018 (Source: own elaboration based on materials of the Municipal Transport Authority, 2018b)

\begin{tabular}{|c|c|c|c|c|}
\hline \multirow{2}{*}{$\begin{array}{c}\text { Line F5: } \\
\text { waterbus stops }\end{array}$} & \multicolumn{2}{|c|}{ Direction: Westerplatte } & \multicolumn{2}{|c|}{ Direction: Żabi Kruk } \\
\hline & Embarking passengers & Disembarking passengers & Embarking passengers & Disembarking passengers \\
\hline Żabi Kruk & 59,0 & 0,0 & 51,3 & 0,0 \\
\hline Zielony Most & 50,1 & 0,3 & 20,8 & 0,2 \\
\hline Targ Rybny & 15,6 & 1,8 & 24,5 & 8,7 \\
\hline Wiosny Ludów & 1,0 & 0,9 & 1,9 & 0,8 \\
\hline Nabrzeże Zbożowe & 0,8 & 2,1 & 2,0 & 0,8 \\
\hline Twierdza Wisłoujście & 0,6 & 3,6 & 0,2 & 2,4 \\
\hline Westerplatte & 5,8 & 54,0 & 2,1 & 41,9 \\
\hline Latarnia Morska & 0,6 & 13,6 & 0,9 & 31,1 \\
\hline Brzeźno & 0,0 & 57,4 & 0,0 & 17,8 \\
\hline Total & 133,5 & 133,5 & 103,8 & 103,8 \\
\hline \multirow{2}{*}{$\begin{array}{l}\text { Line F6: } \\
\text { waterbus stops }\end{array}$} & \multicolumn{2}{|c|}{ Direction: Narodowe Centrum Żeglarstwa } & \multicolumn{2}{|c|}{ Direction: Targ Rybny } \\
\hline & Embarking passengers & Disembarking passengers & Embarking passengers & Disembarking passengers \\
\hline Targ Rybny & 119,5 & 0,0 & 113,0 & 0,0 \\
\hline Wiosny Ludów & 0,2 & 0,1 & 13,7 & 0,6 \\
\hline NCZ & 0,9 & 12,9 & 0,7 & 0,1 \\
\hline Sobieszewo & 0,0 & 107,6 & 0,0 & 126,7 \\
\hline Total & 120,6 & 120,6 & 127,5 & 127,5 \\
\hline
\end{tabular}


The waterbus system's size and capacity supply and land use of areas around stops impact passenger traffic. Since the launch of the waterbus lines in 2012, the number of passengers has been increasing dynamically (Table 2). The average level of filling waterbuses with passengers throughout the entire season was approx. 54.5\%. A high percentage of filling was recorded for line F5, which was served by two small vessels with a capacity of 40 passengers $-79.1 \%$ on average, while for line F6, which was served by a much larger vessel with a capacity of 140 passengers, the average filling rate was $36.0 \%$. The popularity of individual waterbus stops on both lines varied (Table 3 ). For line F5, most of the passenger exchange concentrated at six stops at the opposite ends of the route - three in the historic downtown and three in the coastal strip. It was similar in the case of line F6. The end stops (downtown and the coastal strip) were also the most popular. Both types of areas - the historic downtown and the coastal strip concentrate the most important tourist values. Thus, the structure of passenger exchange indirectly indicates the dominant tourist function of waterbuses.

Annual surveys of tourists and visitors (Bęben et al., 2018) identify the places most frequently visited by them. Among 22 sites and attractions mentioned in the report, visited the most during their stay in 2017, there were as many as 15 situated near (distance up to $1000 \mathrm{~m}$ ) the waterbus stops. The above-mentioned sites usually have cultural values - this is, of course, the historic downtown, as well as museums and theaters located in its area or nearby (Table 4, Figure 3). Gdańsk beaches are a highly appreciated value, and the only natural one. Close to stops, there are three well-known bathing areas: Brzeźno, Górki Zachodnie and Sobieszewo. The beaches of the latter one are slightly farther away (about 1.5-2 km) from the waterbus stop. As evidenced by the data on passenger exchange, this stop is still very popular. It seems that trips to Sobieszewo, due to the time and frequency of cruises, are usually all-day. The greater distance between the bus stop and the beach is not such a big barrier, especially as the large tram capacity on this line is conducive to taking bicycles. Aside from the main considerations, it is worth noting that the areas located by the water are an attraction not only for tourists and visitors to Gdańsk, but also for its inhabitants. As the research by Gurgul (2018) shows, as many as $79 \%$ of the respondents confirmed that they spend time by the water near their place of residence. The average distance covered for this purpose is $1 \mathrm{~km}$. The areas around the Motława and its moat, as well as the coastal strip from Jelitkowo to Górki Zachodnie, are definitely the most popular. Less, but noticeable interest is recorded by the Vistula quays adjacent to residential area, namely in Nowy Port and Wisłojuście, Przeróbka and Sobieszewo. All these places are located close to waterbus stops.

Table 4. Sites and tourist attractions most frequently chosen by respondents in Gdańsk in 2017 which they intended to visit during their stay (multiple choice question), located in the vicinity (up to $1000 \mathrm{~m}$ ) of ferry and waterbus stops (Source: Bęben et al., 2018: 32-33)

\begin{tabular}{|c|c|c|c|c|c|}
\hline $\begin{array}{l}\text { Tourist attraction (the numbering below is consistent } \\
\text { with the reference numbers of items on Figure } 3 \text { ) }\end{array}$ & Total & Visitors & Tourists & Domestic & Foreign \\
\hline 1. Historic Center (Old Town) & $89.91 \%$ & $84.29 \%$ & $93.52 \%$ & $89.09 \%$ & $93.91 \%$ \\
\hline 2. Beach & $44.34 \%$ & $27.35 \%$ & $55.24 \%$ & $40.65 \%$ & $62.30 \%$ \\
\hline 3. Crane (going inside) & $14.51 \%$ & $5.51 \%$ & $20.29 \%$ & $13.41 \%$ & $19.91 \%$ \\
\hline 4. St. Mary's Basilica (going inside) & $23.37 \%$ & $10.10 \%$ & $31.87 \%$ & $21.10 \%$ & $34.43 \%$ \\
\hline 5. Artus Court & $11.56 \%$ & $3.88 \%$ & $16.49 \%$ & $11.63 \%$ & $11.24 \%$ \\
\hline 6. Main Town Hall & $18.86 \%$ & $9.90 \%$ & $24.61 \%$ & $19.03 \%$ & $18.03 \%$ \\
\hline 7. Westerplatte & $20.69 \%$ & $9.69 \%$ & $27.75 \%$ & $19.46 \%$ & $26.70 \%$ \\
\hline 8. Uphagen's House (going inside) & $7.26 \%$ & $2.14 \%$ & $10.54 \%$ & $6.39 \%$ & $11.48 \%$ \\
\hline 9. Gdańsk Shakespearean Theatre & $7.97 \%$ & $2.24 \%$ & $11.65 \%$ & $7.02 \%$ & $12.65 \%$ \\
\hline 10. Sołdek (going inside) & $8.29 \%$ & $1.84 \%$ & $12.43 \%$ & $7.93 \%$ & $10.07 \%$ \\
\hline 11. Wisłoujście Fortress & $7.26 \%$ & $1.53 \%$ & $10.93 \%$ & $6.49 \%$ & $11.01 \%$ \\
\hline 12. National Museum (including Memling's Last Judgment) & $8.73 \%$ & $2.65 \%$ & $12.63 \%$ & $7.64 \%$ & $14.05 \%$ \\
\hline 13. Lighthouse in Nowy Port & $4.86 \%$ & $0.61 \%$ & $7.59 \%$ & $4.13 \%$ & $8.43 \%$ \\
\hline 14. National Maritime Museum & $6.46 \%$ & $2.45 \%$ & $9.03 \%$ & $5.62 \%$ & $10.54 \%$ \\
\hline 15. Museum of the Second World War & $12.52 \%$ & $8.88 \%$ & $14.86 \%$ & $11.77 \%$ & $16.16 \%$ \\
\hline
\end{tabular}

\section{CONCLUSION}

The conducted research procedure clearly showed that the dominant function of the waterbus in Gdańsk is the service of tourist traffic. This is determined by three categories of factors. Firstly, the nature of the system - seasonal, with a relatively low frequency of connections, a separate fare system, using vessels not fully adapted to the effective handling of daily transport flows. Secondly, a low potential demand for transport services due to the remoteness of most stops from large clusters of places of residence or work, as well as the a lack of competitiveness of this offer (travel time and cost, frequency of trips) in comparison to travel by tram or bus. Thirdly, the proximity to most of the city's most important tourist attractions to the stops as well as the significant competitive advantage of waterbuses (travel time) over other means of public transport resulting from the spatial structure of the water and road network. Waterbuses compensate for the lack of bridges that would facilitate movement between tourist attractions located on opposite banks of the river.

The obtained results are helpful in programming the development of public transport systems, especially in large coastal cities which are also important centers of tourist traffic. The determinants of spatial development seem to be of key importance for shaping the dominant function of the waterbus. The main limitation of this study is impossibility to find out the opinion of waterbus users. Direct passenger survey, however difficult in given circumstances, would allow deepening the research and nuancing the knowledge about the reasons for using waterbuses, travel directions or the assessment of the transport service itself. The broader question of transport as a factor of tourist satisfaction with destination place (Carvache-Franco et al., 2018; Mashapa et al., 2019) seems to be impressive research field. This is also the suggested direction for further research. A particularly interesting issue seems to be the extent to which the waterbus system itself and the possibility of seeing interesting, sometimes otherwise inaccessible parts of the city from the water (shipyards, port quays) constitute a tourist attraction in itself. In addition, in the light of the gradual modernization of inland navigation systems in the world, it is worth undertaking research on the directions of such modernization, taking into account local conditions and factors that may be different depending on the city.

\section{Acknowledgement}

The authors would like to thank the anonymous reviewers for their valuable comments and suggestions.

\section{REFERENCES}

Bandyopadhayay, A., \& Banerjee, A. (2017). In pursuit of a sustainable traffic and transportation system: a case study of Kolkata. International Journal of Management Practice, 10(1), 1-16. https://doi.org/10.1504/IJMP.2017.080646 
Bignon, E., \& Pojani, D. (2018). River-based public transport: Why won't Paris jump on board?. Case Studies on Transport Policy, 6(2), 200-205. https://doi.org/10.1016/j.cstp.2018.05.002

Bęben, M., Papis O., \& Cińcio-Pętlicka A. (2018). Turystyka Gdańska. Raport roczny za 2017 r. [Tourism in Gdańsk. 2017 Annual Report]. Pomorski Instytut Naukowy im. prof. Brunona Synaka, Gdańsk, Poland, (in Polish).

Carvache-Franco, M., Carvache-Franco, O., Carvache-Franco, W., Villagómez Buele, C., \& Arteaga Peñafiel, M. (2018). The tourist demand from the perspective of the motivation, assessment and satisfaction in a sun and beach destination: the Manta case, Ecuador. GeoJournal of Tourism and Geosites. 22(2), 561-572. https://doi.org/10.30892/gtg.22224-311

Cheemakurthy, H., Tanko, M., \& Garme, K. (2017). Urban waterborne public transport systems: An overview of existing operations in world cities. KTH Royal Institute of Technology in Stockholm, Stockholm, Sweden.

Chen, Y., Luo, S., Zhang, M., Shen, H., Xin, F., \& Luo, Y. (2017). Modeling service time reliability in urban ferry system. Modern Physics Letters B, 31(26), 1750242. https://doi.org/10.1142/S0217984917502426

Cieśliński, R., \& Chromniak, Ł. (2013). Tramwaje wodne jako nowa forma zagospodarowania dróg wodnych aglomeracji trójmiejskiej [Water trams as a new form of waterways development in the Tri-City agglomeration]. Geography and Tourism, 1(1), 93-100, (in Polish).

Ercoli, S., Ratti, A., \& Ergül, E. (2015). A Multi-method Analysis of the Accessibility of the Izmir Ferry System. Procedia Manufacturing, 3, 2550-2557. https://doi.org/10.1016/j.promfg.2015.07.553

Gagatsi, E., Estrup, T., \& Halastis, A. (2016). Exploring the potentials of electrical waterborne transport in Europe: the E-ferry concept. Transportation Research Procedia, 14, 1571-1580. https://doi.org/10.1016/j.trpro.2016.05.122

Gil Solá, A., Vilhelmson, B., \& Larsson, A. (2018). Understanding sustainable accessibility in urban planning: Themes of consensus, themes of tension. Journal of Transport Geography, 70, 1-10. https://doi.org/10.1016/j.jtrangeo.2018.05.010

Ghosh, B., \& Schot, J. (2018). Mapping Socio-Technical Change in Mobility Regimes: The Case of Kolkata. SPRU Working Paper Series, 16, 1-45.

Große, J., Olafsson, A.S., Carstensen, T.A., \& Fertner, C. (2018). Exploring the role of daily "modality styles" and urban structure in holidays and longer weekend trips: Travel behaviour of urban and peri-urban residents in Greater Copenhagen. Journal of Transport Geography, 69, 138-149. https://doi.org/10.1016/j.jtrangeo.2018.04.008

Guarnieri, M., Morandin, M., Ferrari, A., Campostrini, P., \& Bolognani, S. (2018). Electrifying Water Buses: A Case Study on Diesel-to-Electric Conversion in Venice. IEEE Industry Applications Magazine, 24(1), 71-83. https://doi.org/10.1109/MIAS.2017.2739998

Gurgul, M. (2018). Analiza wyników ankiety „Jak urzadzić gdańskie nabrzeża?”' [The analysis of survey results 'How to arrange Gdańsk quays?']. Biuro Rozwoju Gdańska, Gdańsk, Poland, (in Polish).

Kizielewicz, J. (2014). Wpływ funduszy Unii Europejskiej na rozwój gospodarki turystycznej w obszarach nadmorskich w Polsce - przykład Wybrzeża Gdańskiego [The Impact of EU Funds on the Development of the Tourism Market in the Coastal Regions in Poland - the Case Study of the Gdańsk Coast]. Przegląd Zachodniopomorski, 3(2), 117-125, (in Polish).

Le-Klähn, D.T., \& Hall, M. (2015). Tourist use of public transport at destinations - a review. Current Issues in Tourism, 18(8), 785-803. https://doi.org/10.1080/13683500.2014.948812

Mashapa, M.M., Maziriri, E.T., \& Madinga, W. (2019). Modeling key selected multisensory dimensions on place satisfaction and place attachment among tourists in Victoria Falls, Zimbabwe. GeoJournal of Tourism and Geosites, 25(2), 580-594. https://doi.org/10.30892/gtg.25224-382

Miszewska-Urbańska, E., \& Apollo, M. (2016). Comparative analysis of transport organization and functioning of water trams in Gdansk, Bydgoszcz and Krakow. Advances in Science and Technology. Research Journal, 10(29), 116-124. https://doi.org/10.12913/22998624/61939

Obrochta, K. (2019). Siedem polskich miast w rankingu 100 miejsc, które warto odwiedzić w 2017 wg Trivago [Seven Polish cities in the ranking of 100 places worth to visit in 2017 by Trivago]. (in Polish). http://ie1.trivago.com/contentimages/press2/images /Best_Value_Index_2017.pdf

Połom, M., Tarkowski, M., \& Puzdrakiewicz, K. (2020). Warunki i perspektywy rozwoju wewnatrzmiejskiej żeglugi pasażerskiej w Gdańsku [Conditions and perspectives for the development of intra-city passenger shipping in Gdańsk]. Prace Komisji Geografii Komunikacji PTG, 23(1), 58-75, (in Polish). https://doi.org/10.4467/2543859XPKG.20.011.12113

Sandell, R. (2017). Network Design Strategies to Increase Efficiency and Usefulness of Urban Transit Ferry Systems. Transportation Research Record: Journal of the Transportation Research Board, 2649, 71-78. https://doi.org/10.3141/2649-08

Sheller, M., \& Urry, J. (2016). Mobilizing the new mobilities paradigm. Applied Mobilities, 1(1), 10-25. https://doi.org/10.1080/23800127.2016.1151216

Tan, P.Y., \& Ismail, H.N. (2020). Reviews on interrelationship between transportation and tourism: Perspective on sustainability of urban tourism development. IOP Conference Series: Earth and Environmental Science, 447, 012065.

Tanko, M., \& Burke, M.I. (2017). Transport innovations and their effect on cities: the emergence of urban linear ferries worldwide. Transportation Research Procedia, 25C, 3961-3974. https://doi.org/10.1016/j.trpro.2017.05.483

Thompson, R., Burroughs, R., \& Smythe T. (2007). Exploring the connections between ferries and urban form: Some consideration s before jumping on board. Journal of Urban Technology, 13(2), 25-52. https://doi.org/10.1080/10630730600872021

*** Gdańsk Buses and Trams. (2020). Pojazdy [Vehicles]. (in Polish). https://www.gait.pl/firma/pojazdy/

*** Gdańsk Development Office. (2016). Gdańskie Badania Ruchu 2016 wraz z opracowaniem transportowego modelu symulacyjnego dla Gdańska. Raport 3 - raport z przeprowadzenia badań i pomiarów [Gdańsk Traffic Research 2016 with the development of a transport simulation model for Gdańsk. Report 3 - results]. Biuro Rozwoju Gdańska, Gdańsk, (in Polish).

*** Gdańsk Development Office. (2018). Studium uwarunkowań i kierunków zagospodarowania przestrzennego miasta Gdańska [Study of conditions and directions of spatial development in the City of Gdańsk]. Biuro Rozwoju Gdańska, Gdańsk, (in Polish).

*** Gdańsk Economic Development Agency. (2018). Analiza funkcjonowania tramwaju wodnego w Gdańsku od 2018 r. [Functioning analysis of Gdańsk waterbus since 2018]. Gdańska Agencja Rozwoju Gospodarczego, Gdańsk, Poland, (in Polish).

*** Geoportal. (2018). Database of Topographic Object. (in Polish). https://www.geoportal.gov.pl/dane/baza-danych-obiektow-topograficznych-bdot

*** Municipal Transport Authority. (2018a). Gdański Tramwaj Wodny przewiózł w tym roku ponad 65 tys. osób! [Gdańsk Waterbus carried over 65 thous. passengers this year!]. (in Polish). https://ztm.gda.pl/wiadomosci/to-dopiero-byl-sezon-gdanski-tramwaj-wodny-przewiozl-w-tym-roku-ponad-65-tys-osob,a,3913

*** Municipal Transport Authority. (2018b). Liczba pasażerów tramwajów wodnych w okresie maj - wrzesień 2018 [Number of waterbus passengers in the period of May - September 2018]. Zarząd Transportu Miejskiego, Gdańsk, Poland, (in Polish).

*** Municipal Transport Authority. (2020). Lista tras i przystanków [Routes and stops database]. (in Polish). https://www.ztm.gda.pl/rozklady/przystanki.html

*** Pomeranian Scientific Institute. (2017). Turystyka w Gdańsku w okresie letnim 2017. Czerwiec, lipiec, Sierpień [Tourism in Gdańsk in the summer season of 2017. June, July, August]. (in Polish). https://app.xyzgcm.pl/visitgdansk-pl/d/2018083439/infografika-turystyka-w-gdan-sku-w-okresie-letnim-2017-r.pdf 